\title{
SEJARAH INTELEKTUAL ISLAM INDONESIA Studi kasus Pemikiran Nurchalish Madjid Dan Hamka (Studi Perbandingan)
}

\author{
Oleh : Nasruddin
}

\begin{abstract}
Abstrak
Nurchalish Madjid dalam pemikirannya tentang sekulerisasi, bahwa bukan penerapan sekularisme dan mengubah kaum muslimin menjadi sekularis." Tetapi dimaksudkan untuk menduniawikan nilai-nilai yang sudah semestinya bersifat duniawi dan melepaskan umat Islam dari kecenderungan untuk mengukhrowikannya. Jika Indonesia kembali pada fundamentalisme Islam ibarat bahaya narkotika yang selalu membekas dalam diri manusia, paham Pluralitas masyarakat adalah bagian amat penting dari tatanan masyarakat maju. Dalam paham itulah dipertaruhkan, antara lain sehatnya demokrasi dan keadilan. Pluralisme tidak saja mengisyaratkan adanya sikap bersedia mengakui hak kelompok lain atau ada, tetapi juga mengandung makna kesediaan berlaku adil kepada kelompok lain itu atas dasar perdamaian dan saling menghormati. Buya Hamka, menolak dengan keras apa yang disebut toleransi agama, dan juga menolak dengan keras tentang pluralisme agama juga menolak paham sekularisme. Penghayatan tasawuf hamka itu berupa pengalaman takwa yang dinamis, bukan ingin bersatu dengan tuhan, adapun refleksi tasawuf menurut hamka yaitu berupa menampakkan makin meningginya kepekaan sosial dalam diri si sufi. Jadi intinya secara garis besar, konsep dasar sufistik menurut hamka adalah sufisme yang berorientasi ke depan.
\end{abstract}

Kata kunci: Sejarah; Inteletual; Islam; Indonesia.

\section{A. Latar Belakang Masalah}

Sejarah intelektual ialah sejarah pemikiran yang bersifat tematik. Bidang sejarah intelektual ini telah lama ada pada zaman Greek yang bertumpu kepada aspek agama seperti Kristian dan Islam sebelum abad ke-19 Masehi. Konsep sejarah pemikiran sama dengan sejarah filsafat yaitu kajian mengenai pemikiran manusia. Namun sejarah pemikiran masih mempunyai perbedaan dari sudut tumpuan kajian. Tumpuan kajian sejarah filsafat lebih bersifat khusus dan dikaitkan dengan pemikiran manusia diperingkat yang tinggi. 
Sedangkan tumpuan sejarah pemikiran pula lebih bersifat umum dan melibatkan tahap pemikiran manusia di peringkat biasa dan sederhana. Dengan kata lain, apa yang dikaji dalam sejarah pemikiran adalah merangkum gagasan-gagasan politik, sosial, ekonomi, pendidikan, teologi kebudayaan dan lain-lain. Dan yang terpenting ialah adanya kesan dan pengaruh gagasan tersebut terhadap pemikiran, tindakan dan perkembangan masyarakat manusia.

Berpikir merupakan salah satu kegiatan manusia yang sudah dilakukan sejak manusia ada. Hasil-hasil pemikiran manusia pada masa lampau merupakan kajian dari sejarah intelektual. Pemikiran-pemikiran yang lahir dari kegiatan manusia di masa lampau memiliki berbagai tema. Tema-tema tersebut menyangkut pemikiran filsafat, politik, ekonomi, agama dan yang lainnya. Oleh karena itu, sejarah intelektual dapat didefinisikan sebagai the study of the role of ideas in historical events and process. Secara lebih kongkrit sejarah intelektual mencakup studi tentang pemikiran-pemikiran besar, yang berpengaruh pada kejadian bersejarah, serta pengaruh pemikiran tersebut pada masyarakat bawah. Sejarah Intelektual merupakan sejarah yang abstrak tapi tidak sepenuhnya karena adanya kehidupan yang konkret.

Sebagaimana di Indonesia beragamnya corak pemikiran keagamaan yang berkembang dalam sejarah Islam di Indonesia dari Islam yang bercorak sufistik, tradisionalis, revivalis dan modernis hingga neo-modernis-dengan jelas memperteguh kekayaan khazanah keislaman negeri ini. Fenomena ini juga membuktikan beragamnya pengaruh yang masuk ke dalam wacana Islam yang berkembang di kepulauan Nusantara. Dalam perspektif sejarah perkembangan intelektual, ini menunjukkan bahwa telah terjadi pergeseran visi dan orientasi di dalam corak pemahaman keagamaan di kalangan Muslim Indonesia. Periode akhir abad ke 16 sampai akhir abad ke 19 bahkan memunculkan tongggak awal intelektualisme Islam di Indonesia yang cemerlang dengan melalui karya-karya monumental.

Haji Abdul Karim Amrullah (Hamka) dan Nurchalish Madjid adalah dua tokoh intelektual Islam Indonesia yang memberikan pemikiran baru, yang dampaknya melahirkan kajian-kajian baru bahkan tidak luput dari perdebatan yang sengit dari berbagai kalangan pemikir-pemikir lainnya. Baik Pemikirannya tentang pluralisme, pendidikan, teologi dan modernisme. Penulis pada kesempatan kali ini ingin melihat perbadingan pemikiran Buya Hamka dan Nurchalish Majid. Dari semua ini melahirkan pertanyaan Bagaimana Biografi Nurchalish Madjid dan Buya Hamka ? Bagaimana pemikiran Buya Hamka dan Nurchalish Madjid tentang Plurlisme, modernis Pendidikan Islam dan Teologi.

\section{B. Biografi dan pemikiran Nurchalis Madjid dan Buya Hamka.}

Arus liberalisasi dan modernisasi Barat telah mempengaruhi pemikiran serta aqidah umat Islam melalui beberapa aspek kehidupan yang mendasar pada agama. Pluralisme agama, dianggap sebagai gerakan pembaharuan pemikiran Islam fundamental dan tradisional berujung pada deskontruksi ajaran Islam oleh pemikir 
Islam Liberal. Gagasan tersebut merupakan sumbangsi otoritas para orientalis serta missionaris barat kepada umat Islam agar mereka berkiblat kepada peradaban Barat yang liberal dan sekuler. Hal ini telah di adopsi oleh Nurcholish Majid dalam menyebarkan pemikirannya yang sekuler serta inklusif. Padahal, sejarah peradaban Barat dibangun oleh produktifitas pemikiran ulama muslim. Berbeda dengan Islam yang telah jelas konsep Tuhan dan hidupnya berdasarkan pada wahyu.

Berbagai macam deskontruksi dilakukan dari makna agama Islam, kemajemukan dalam perbedaan agama. Sampai menjujung tinggi paham pluralisme dengan dalih bahwa al-qur'an merupakan firman Allah yang telah menyeru pada persamaan tujuan beragama sampai harusnya Islam memodernisasi priloaku social dan kehidupan. Oleh sebab itu, penulis disini membahas pemikiran Nurcholis Majid yang condong pada 2 faktor utama yaitu sekularisasi dan inklusivisme. Agar kita tidak salah arah dan tujuan terhadap hakekat kemajuan Islam terdapat pada penetapan syari'at Islam.

\section{Biografi Singkat Nurchalish Madjid}

Nurcholis lahir dan dibesarkan di lingkungan keluarga kiai terpandang di Mojoanyar, Jombang, Jawa Timur, pada tanggal 17 Maret 1939. Ayahnya, KH Abdul Madjid, dikenal sebagai pendukung Masyumi. Setelah melewati pendidikan di pesantren (Pesantren Darul 'ulum Rejoso, Jombang, Jawa Timur, sampai tahun 1955, dan kemudian Pesantren Darus Salam, Gontor, Ponorogo, Jawa Timur sampai tahun 1960), ia menempuh studi kesarjanaan di IAIN Syarif Hidayatullah Jakarta (mendapat BA dalam Sastera Arab th. 1965, dan Doktorandus- Sastera Arab th.1968). Kemudian tokoh HMI (Menjabat sebagai ketua HMI dua periode/1966-1971) ini menjalani studi doktoralnya di Universitas Chicago- Amerika Serikat (1978-1984), dengan disertasi tentang Filsafat dan Kalam Ibnu Taimiyah. Bidang yang diminatinya selain Filsafat, adalah: Pemikiran Islam, Reformasi Islam, Kebudayaan Islam, Politik dan Agama, Sosiologi Agama, serta Politik negara-negara berkembang. ${ }^{1}$

Nurcholish aktif mengikuti berbagai kegiatan internasional yang berkaitan dengan permasalahan agama, beberapa di antaranya adalah: Presenter, Seminar Internasional tentang "Agama Dunia dan Pluralisme”, Nopember 1992, Bellagio, Italy; Presenter, Konferensi Internasional tentang "Agama-agama dan Perdamaian Dunia", April 1993, Vienna, Austria; Presenter, Seminar Internasional tentang "Islam di Asia Tenggara", Mei 1993, Honolulu, Hawaii, USA; Presenter, Seminar Internasional tentang "Persesuaian Aliran Pemikiran Islam", Mei 1993, Teheran,

Iran; Presenter, Seminar Internasional tentang "Ekspresi-ekspresi Kebudayaan Tentang Pluralisme", Jakarta 1995, Cassablanca, Morocco; Presenter, seminar internasional tentang "Islam dan Masyarakat sipil", Maret 1995, Bellegio, Italy; Presenter, seminar internasional tentang "Kebudayaan Islam di Asia Tenggara", Juni 1995, Canberra, Australia; Presenter, seminar internasional tentang "Islam dan

1 Abdul Qodir, M.Ag, Jejak Langkah Pemikiran Islam di Indonesia, (Bandung: Pustaka Pelajar, 2004), hal. 105-107. 
Masyarakat sipil", September 1995, Melbourne, Australia; Presenter, seminar internasional tentang “Agama-agama dan Komunitas Dunia Abad ke-21," Juni 1996, Leiden, Netherlands; Presenter, seminar internasional tentang "Hak-hak Asasi Manusia", Juni 1996, Tokyo, Jepang; Presenter, seminar internasional tentang "Dunia Melayu", September 1996, Kuala Lumpur, Malaysia; Presenter, seminar internasional tentang “Agama dan Masyarakat Sipil”, 1997 Kuala lumpur; Pembicara, Konferensi USINDO (United States Indonesian Society), Maret 1997, Washington DC, USA; Peserta, Konferensi Internasional tentang "Agama dan Perdamaian Dunia" (Konferensi Kedua, Mei 1997, Vienna, Austria; Peserta, Seminar tentang "Kebangkitan Islam", Nopember 1997, Universitas Emory, Atlanta, Georgia, USA; Pembicara, Seminar tentang "Islam dan Masyarakat Sipil" Nopember 1997, Universitas Georgetown, Washington DC, USA; Pembicara, Seminar tentang "Islam dan Pluralisme", Nopember 1997, Universitas Washington, Seattle, Washington DC, USA; Sarjana Tamu dan Pembicara, Konferensi Tahunan, MESA (Asosiasi Studi tentang Timur Tengah), Nopember 1997, San Francisco, California, USA; Sarjana Tamu dan Pembicara, Konferensi Tahunan AAR (America Academy of Religion) Akademi Keagamaan Amerika, Nopember 1997, California, USA; Presenter, Konferensi Internasional tentang "Islam dan Hak-hak Asasi Manusia”, Oktober 1998, Geneva, Switzerland; Peserta Presenter "Konferensi Pemimpin-pemimpin Asia", September 1999, Brisbane, Australia; Presenter, Konferensi Internasional tentang "Islam dan Hak-hak Asasi Manusia, pesan-pesan dari Asia Tenggara", Nopember 1999, Ito City, Japan; Peserta, Sidang ke-7 Konferensi Dunia tentang Agama dan Perdamaian (WCRP), Nopember 1999, Amman, Jordan. ${ }^{2}$

Bila di tilik dari ragam pengalamnnya dapat disimpulkan bahwa transformasi peradaban barat sangat banyak menyumbangkan serta membentuk nilai-nilai liberal yang mendasari pola fikirnya khususnya tentang Sekularisme dan Islam inklusivisme.

\section{Pokok-Pokok Pemikiran Nurcholish Majid}

\section{a. Sekulerisme}

To have failed to solve the problem of producing goods wolud have been to continue man in his oldest and grievous misfortune. But to fail to see that we have solved it and to fail to proceed thence to the next task would be fully as tragic. ${ }^{3}$ Kemajuan suatu bangsa akan berhasil apabila problema ditindak lanjuti setelah modernitas itu sendiri telah berhasil diwujudkan dalam bentuk kemudahan hidup dan kemakmuran seperti Barat. Sehingga hal ini membuat Nurcholis Majid mengajukan pernyataan bahwa, apakah Islam relevan bagi kehidupan modern? Masalahnya adalah kum muslim menutup dirinya dengan skriptualisme yang amat kuat, dengan dalih

2 Budi Handrianto, 50 Tokoh Islam Liberal Indonesia, (Jakarta Timur: Hujjah Press 2007), hal. 62-64.

${ }^{3}$ Karl Barth, Ethics, (New York: The Seabury Press, 1981) dikutip oleh Nur Cholis Madjid, Islam Doktrin dan Peradaban, (Jakarta: Paramadina, 2005). 
menjaga kemurnian dan keaslian Kitab Suci dan secara tidak langsung hal ini menghalangi kemodernan atau pembaharuan dalam Islam. Oleh sebab itu dialogdialog umat muslim akan berusaha mengenali siapa yang murni dan mana yang tambahan atau dalam istilah ilmuwan sosial Great Tradition atau Folk Tradition. ${ }^{4}$ Nurcholis Majid menyampaikan gagasan sekulerisasi dengan menganjurkan keharusan pembaharuan pemikiran Islam pertama kali pada tanggal 2 Januari 1970 dalam makalahnya yang berjudul "Keharusan Pembaharuan pemikiran Islam dan Masalah Integrasi Umat." 5

Indonesia saat ini sedang dilanda oleh beberapa gejala yang menurut orang Barat diidentifikasi sebagai ekstrimisme atau fundamentalisme tetapi ketika islam mulai migrasi menuju civil liberties kecemasan itu berkurang. Dengan wacana bebas, bukan hanya kejelasan-kejelasan yang diperoleh tapi juga proses penisbian, relasi dan fisasi bahkan lebih radikal dari itu adalah proses devaluasi. ${ }^{6}$ Oleh sebab itu dalam kaitannya dengan sekularisasi maka kita akan mengenal tiga prinsip dasar dari sekularisasi yaitu :

1) Disenchantment of nature.

Menurut Harvey Cox, senada dengan apa yang diungkapkan oleh Max Weber seorang sosiolog Jerman, dunia perlu dikosongkan dari nilai-nilai agama dan rohani. Yang selanjutnya, sains akan terus berkembang jika dikosongkan dari nilai-nilai agama yang ghaib. Karena itulah tokoh-tokoh agama konservatif, dunia tidak boleh diperlakukan sewenang-wenang. Padahal dengan adanya pembebasan dunia dari agama merupakan kunci utama dalam usaha-usaha urbanisasi dan modernisasi.

2) Desacralization of politik

Dalam hal ini pembebasan nilai dari politik yang berarti bahwa politik tidak sakral. Maka dari itu peran ajaran agama kepada intuisi politik harus disingkirkan. Karena dalam masyarakat sekuler tidak seorangpun berhak memerintah secara otoritas " kuasa suci ".

3) Decansencration of value

Prinsip sekularisasi yang ketiga ini adalah pembebasan nilai yang ada atau merelatifkan nilai. Menurut sekularis tidak ada yang absolute di dunia ini semuanya bersifat relative tidak ada kebenaran yang mutlak.. dalam artian system nilai manusia secular harus dikosongkan dari agama karena perspekti seseorang dipengaruhi oleh factor social budaya.

${ }^{4}$ Nur Cholis Madjid, Islam Doktrin dan Peradaban, (Jakarta: Paramadina, 2005), hal. 468469.

5 Adnin Armas, dkk, Menelusuri Gagasan Sekularisasi Nurcholis Majid, Jurnal Tsaqafah Jurnal

Ilmu Pengetahuan dan Kebudayaan Islam, ( Volume 4, No.2, Jumadal Ula 1428), h. 399. 62.

${ }^{6}$ Jaringan Islam Liberal, Ijtihad Islam Liberal, (Jakarta: Jaringan Islam Liberal, 2005), h. 61- 
Jadi sekulerisasi menurutnya, " Bukan penerapan sekularisme dan mengubah kaum muslimin menjadi sekularis." Tetapi dimaksudkan untuk menduniawikan nilainilai yang sudah semestinya bersifat duniawi dan melepaskan umat Islam dari kecenderungan untuk mengukhrowikannya. Jika Indonesia kembali pada fundamentalisme Islam ibarat bahaya narkotika yang selalu membekas dalam diri manusia, pernyataan itu sesuai dengan cuplikan pidatonya yang menghebohkan ketika menyampaikan pidato keagamaan di Taman Ismail Marzuki 21 Oktober 1992: " Karena itu, bagaimanapun, kultus dan fundamentalisme hanyalah pelarian dalam keadaan tidak berdaya. Sebagai sesuatu yang hanya memberi hubungan ketenangan semu atau palliative, kultus dan fundamentalisme adalah sama berbahayanya dengan narkotika. Namun, narkotika menampilkan bahaya hanya melalui pribadi yang tidak memiliki kesadaran, baik secara individual maupun kelompok karena tidak berpengaruh terhadap kulture sosial. Adapun kultus dan fundamentalisme dengan sendirinya melahirkan gerakan dengan disiplin tinggi, maka penyakit yang terakhir ini lebih berbahaya dari pada yang pertama........Sebagaimana mereka memandang narkotika dan alkoholisme sebagai ancaman bagi kelangsungan daya tahan bangsa, mereka juga berkeyakinan bahwa kultus dan fundamentalisme adalah ancamanancaman yang tidak kurang gawatnya."

Akhirnya pidato itu menuai kritik dari berbagai kalangan, sebab istilah fundamentalisme tanpa disertai definisi yang jelas dan pada akhirnya berujung kepada proses stigmatisasi terhadap sebagian kalangan muslim yang berjuang menegakkan syari'at Islam. ${ }^{7}$ Bagi Cak Nur iman dan aqidah adalah suatu hal yang bebeda, iman menuntut sikar rendah hati, selalu terbuka bagi semua informasi kebenaran tetapi sekaligus juga dinamis untuk mengejar kebenaran itu dari sumbernya, yaitu Sang Kebenaran itu sendiri yang oleh al-Qur'an, Dia Yang Maha Benar itu disebut Allah Swt. Sementara akar dari sekuleralisme merupakan modernisasi ang diorentasikan pada rasionalisasi pemikiran secara sistematis dan efisien. ${ }^{8}$ Islam pada hakikatnya tidak berbicara tentang bentuk negara maupun proses perpindahan kekuasaan seperti otoritas kaum fundamental. Tetapi doktrin qur'an menyebutkan bahwa negara yang baik penuh dengan ampunan Tuhan karena kesatuan umat yang universal bukan Islamic State ${ }^{9}$, hal ini sesuai dengan firman Allah dalam QS al Hujarat/49: 13

${ }^{7}$ Budi Handrianto, 50 Tokoh Islam Liberal Indonesia,........h. 65-66.

${ }^{8}$ Abdul Qodir, Jejak Langkah Pemikiran Islam di Indonesia, (Bandung: Pustaka Pelajar, 2004). h. 137

${ }^{9}$ Abdul Qodir, Jejak Langkah... h. 143-144. 


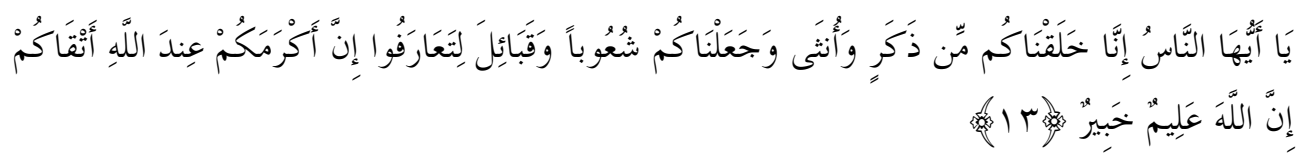

Terjemahnya

Hai manusia, sesungguhnya Kami menciptakan kamu dari seorang laki-laki dan seorang perempuan dan menjadikan kamu berbangsa-bangsa dan bersukusuku supaya kamu saling kenal mengenal. Sesungguhnya orang yang paling mulia di antara kamu di sisi Allah ialah orang yang paling bertakwa di antara kamu. Sesungguhnya Allah Maha Mengetahui lagi Maha Mengenal.

\section{b. Pemikiran Teologi Nurchalish Madjid.}

Teologi Ekslusivisme merupakan paham tertutup yang tidak mau menerima segala sesuatu yang datang dari luar golongannya. Poenjunjung pemikiran tersebut adalah para fundamentalisme yang menggaris bawahi bahwa dunia Islam terus menerus mengalami kemunduran karena sebab eksternal melalui invansi dan serangan kultural politik dan ekonomi barat maupun internal sebagai nilai serta pengaruh dari faktor eksternal.

Sedangkan inklusivisme adalah paham terbuka yang mau menerima segala yang (positif) datang dari luar. Orang-orang Eksklusif memandang orang lain berdasarkan keturunan, agama, ras, suku, dan golongan. Mereka tidak mau menerima orang yang dianggapnya tidak cocok dengan paham atau mazhab yang dianut alirannya. Hal ini kemudian akan menciptakan sebuah tindakan tertutup yang tidak mau menerima perubahan, kemajemukan, dan pluralisme agama (dalam konteks agama). Mungkin dalam Islam, sosok Al-Ghazali bisa dijadikan sebagai wakil dari sekian tokoh Islam yang menganut paham eksklusif ini. Dia sangat tertutup terhadap filsafat. Bahkan sampai-sampai dia mengeluarkan klaim ateis atau kafir terhadap tiga filosof muslim klasik secara terang-terangan dalam bukunya tahafutul falasifah. Sedangkan Teologi Inklusif sangat berbeda dari ekslusivisme di atas, inklusivisme memandang orang lain dengan lebih arif dan bijak. Orang-orang inklusif ini sangat menghargai adanya pluralisme, perbedaan, dan kemajemukan. Mereka memandang semuanya sama seperti dirinya sendiri. Politik pengkafiran pun tidak berkembang dalam paham ini. Oleh karena itu, bisa dikatakan bahwa orang inklusif lebih mulia dari pada eksklusif. Jika di eksklusif ada al-Ghazali, maka tokoh utama yang menganut paham inklusif ini terpotret pada sosok Ibnu Rusyd. Beliau sangat menjunjung rasionalitas dan pluralitas, keberagaman dan kemajemukan, baik dibidang agama maupun budaya, dan nilai-nilai universalitas lainnya. Berangkat dari fenomena seperti itu, teologi inklusif adalah salah satu solusi yang solutif guna menghapus (mendekonstruksi) paham jumud dan ekslusif yang telah "membumi" dalam Islam di Indonesia. Dengan teologi inklusif ini, Islam dapat berkembang ke arah yang lebih baik dan maju. Maka dari itu, sekali lagi, untuk keluar dari keterupurukan dan keterbelakangan pemikiran yang kini mendera umat Islam di 
dunia dan di Indonesia khususnya, harus menjadikan teologi inklusif sebagai satusatunya paradigma dalam menyikapi realitas. Teologi inklusif, dengan demikian, adalah suatu kemanusiaan universal yang dalam al-qur'an sesuai dengan firman Allah dalam QS al Rum/60: 30

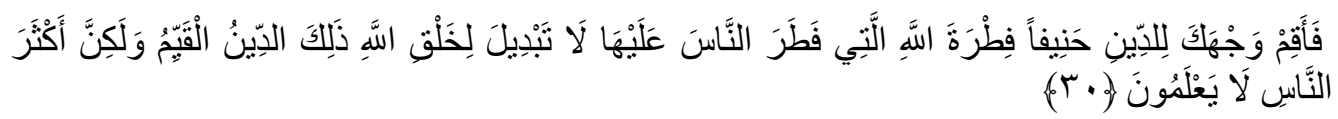

\section{Terjemahnya}

Maka hadapkanlah wajahmu dengan lurus kepada agama (Allah); (tetaplah atas) fitrah Allah yang telah menciptakan manusia menurut fitrah itu. Tidak ada perubahan pada fitrah Allah. (Itulah) agama yang lurus; tetapi kebanyakan manusia tidak mengetahui.

Ayat ini memaparkan tentang wujud agama yang benar bagi setiap iman beragama karena dalam kemajemukan terdapat satu kesatuan yang esoterik. Karena paham kemajemukan masyarakat adalah bagian amat penting dari tatanan masyarakat maju. Dalam paham itulah dipertaruhkan, antara lain sehatnya demokrasi dan keadilan. Pluralisme tidak saja mengisyaratkan adanya sikap bersedia mengakui hak kelompok lain atau ada, tetapi juga mengandung makna kesediaan berlaku adil kepada kelompok lain itu atas dasar perdamaian dan saling menghormati.

Jelas bahwa bangsa kita akan memperoleh manfaat besar dalam usaha transformasi sosialnya menuju demokrasi dan keadilan jika pluralisme itu dapat ditanamkan dalam kesadaran kaum Muslimyang merupakan golongan terbesar warga negara. Secara intern, pluralisme adalah persyaratan pertama dan ukhuwah Islamiyah. ${ }^{10}$ Nurcholis tampak berupaya melakukan deskontruksi makna Islam sebagai suatu nama agama dengan makna generik, yakni sikap pasrah dan kepatuhan terhadap hukum syari'ah. Pada dasarnya Islam bersifat inklusif dan merentangkan kearah pluralis dengan menyatakan bahwa setiap agama mempunyai ekspresi keimanan terhadap tuhan yang sama ibarat roda yang berputar, pusat roda tersebut adalah tuhan yang sama melalui jalan berbagai agama yang heterogen tapi satu makna. ${ }^{11}$ "Jadi Pluralisme adalah sunnatullah sebuah aturan khusus dari tuhan yang tidak akan berubah, sehingga tidak mungkin juga dilawan atau diingkari." 12

\section{c. Islam Sebagai "Common Flatform" (Kalimatun Sawa') Agama-Agama}

${ }^{10}$ Nur Cholis Majid, Doktrin Peradan Islam,...h. 602.

${ }^{11}$ Nur Cholis Majid, Doktrin Peradan Islam,..h. 602.

12 Jalaluddin Rakhmat, Islam dan Pluralisme Akhlaq Qur'an Meyikapi Perbedaan, ( Jakarta: Serambi Ilmu Semesta, 2006), h. 38. 
Nurchalish Madjid berwacana kesatuan agama pada level esoteris. Dalam hal ini Nurcholish Madjid menafsirkan "Islam" (sikap pasrah kepada Tuhan) sebagai titik temu dan inti dari semua ajaran agama yang benar dari sisi Allah Swt. Nurchalishh Madjid menyebutnya sebagai Kalimatun Sawa'atau Common Flatform Agamaagama. Ia juga menukil pendapat Yusuf Ali, seorang komentator Al-Qur'an dalam karyanya "The Holy Qur'an, Translation and Commentary" yang menyatakan bahwa Islam bukanlah sebuah sekte atau sebuah agama etnis. Dalam pandangan Islam, semua agama adalah satu (sama), karena Kebenaran adalah satu (sama). Islam adalah agama yang diajarkan oleh semua nabi terdahulu. Islam adalah kebenaran yang diajarkan oleh semua kitab suci yang diwahyukan.

Untuk menjustifikasi pendapatnya, Nurcholish Madjid selalu bersandar pada firman Allah Swt. dalam QS Alu 'Imrân/3 : 64 berikut ini :

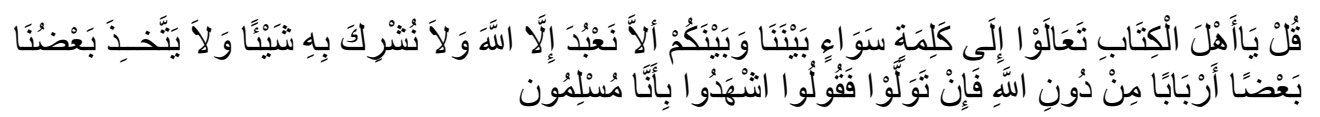

Terjemahnya

Katakanlah olehmu (Muhammad): "Wahai Ahli Kitab! Marilah menuju ke titik pertemuan (kalimah sawa') antara kami dan kamu yaitu bahwa kita tidak menyembah selain Allah dan tidak pula memperserikatkan-Nya kepada apapun, dan bahwa sebagian dari kita tidak mengangkat sebagian yang lain sebagai ‘tuhan-tuhan' selain Allah.

Resistensi yang ditampakkan oleh komunitas Ahli Kitab tidak rumit untuk dapat dipahami. Hal sedemikian karena, ayat tersebut di atas tidak berhenti pada seruan "Wahai Ahli Kitab! Marilah menuju ke titik pertemuan (kalimah sawa') antara kami dan kamu,"melainkan secara kongkret menawarkan tiga konsensus teologis sekaligus sebagai flatform bersama ; 1) tidak menyembah selain Allah; 2) tidak berbuat syirik atau menyektukan Tuhan'; dan 3) tidak mempertuhankan sesama manusia.

Nurcholish Madjid menegaskan perbedaan-perbedaan manifestasi kenyataan sehari-hari (ritual) tetap berporos pada yang satu ajaran (common flatform, kalimatun sawa') yaitu; semuanya menjalankan kepasrahan untuk menuju Kebenaran Yang Absolut, Tuhan (wilayah esoteris). manifestasi lahiriah al-Islâm itu dapat beraneka raga, antara lain karena mengikuti zaman dan tempat. Namun dalam keanekaragaman itu, semua orang (harus) mengabdi dan berbakti kepada Wujud Yang Satu, yaitu Tuhan.

Penganut kesatuan transenden agama-agama dengan istilah 'kesatuan' itu adalah bukan bagian-bagian yang membentuk totalitas yang padu, tetapi merupakan 'totalitas' itu sendiri, maka 'kesatuan' itu bukan bermakna 'kesamaan agama'. Tapi, para pengusung konsep kesatuan transenden agama-agama telah bicara tentang konsep Tuhan itu pada level transcendent dimana masing-masing agama dianggap 
sah di dalam bentuknya yang terbatas dan menyampaikan kebenaran yg sama secara terbatas pula.

\section{Biografi Buya Hamka.}

Hamka juga diberikan sebutan Buya, yaitu panggilan buat orang Minangkabau yang berasal dari kata abi, abuya dalam bahasa Arab, yang berarti ayahku, atau seseorang yang dihormati. Ayahnya adalah Syekh Abdul Karim bin Amrullah, yang dikenal sebagai Haji Rasul, yang merupakan pelopor Gerakan Islah (tajdid) di Minangkabau, sekembalinya dari Makkah pada tahun 1906. Beliau dibesarkan dalam tradisi Minangkabau. Masa kecil HAMKA dipenuhi gejolak batin karena saat itu terjadi pertentangan yang keras antara kaum adat dan kaum muda tentang pelaksanaan ajaran Islam. Banyak hal-hal yang tidak dibenarkan dalam Islam, tapi dipraktikkan dalam kehidupan masyarakat sehari-hari. Putra HAMKA bernama H. Rusydi HAMKA, kader PPP, anggota DPRD DKI Jakarta. Anak Angkat Buya Hamka adalah Yusuf Hamka, Chinese yang masuk Islam.

\section{Riwayat Pendidikan Hamka}

HAMKA di Sekolah Dasar Maninjau hanya sampai kelas dua. Ketika usia 10 tahun, ayahnya telah mendirikan Sumatera Thawalib di Padang Panjang. Di situ HAMKA mempelajari agama dan mendalami bahasa Arab. HAMKA juga pernah mengikuti pengajaran agama di surau dan masjid yang diberikan ulama terkenal seperti Syeikh Ibrahim Musa, Syeikh Ahmad Rasyid, Sutan Mansur, R.M. Surjopranoto dan Ki Bagus Hadikusumo.

Sejak muda, HAMKA dikenal sebagai seorang pengelana. Bahkan ayahnya, memberi gelar Si Bujang Jauh. Pada usia 16 tahun ia merantau ke Jawa untuk menimba ilmu tentang gerakan Islam modern kepada HOS Tjokroaminoto, Ki Bagus Hadikusumo, RM Soerjopranoto, dan KH Fakhrudin. Saat itu, HAMKA mengikuti berbagai diskusi dan training pergerakan Islam di Abdi Dharmo Pakualaman, Yogyakarta.

\section{Riwayat Karier HAMKA}

HAMKA bekerja sebagai guru agama pada tahun 1927 di Perkebunan Tebing Tinggi, Medan. Pada tahun 1929 di Padang Panjang, HAMKA kemudian dilantik sebagai dosen di Universitas Islam, Jakarta dan Universitas Muhammadiyah, Padang Panjang dari tahun 1957- 1958. Setelah itu, beliau diangkat menjadi rektor Perguruan Tinggi Islam, Jakarta dan Profesor Universitas Mustopo, Jakarta.

Sejak perjanjian Roem-Royen 1949, ia pindah ke Jakarta dan memulai kariernya sebagai pegawai di Departemen Agama pada masa KH Abdul Wahid Hasyim. Waktu itu HAMKA sering memberikan kuliah di berbagai perguruan tinggi 
Islam di Tanah Air. Dari tahun 1951 hingga tahun 1960, beliau menjabat sebagai Pegawai Tinggi Agama oleh Menteri Agama Indonesia. Pada 26 Juli 1977 Menteri Agama Indonesia, Prof. Dr. Mukti Ali, melantik HAMKA sebagai Ketua Umum Majlis Ulama Indonesia tetapi beliau kemudian meletakkan jabatan itu pada tahun 1981 karena nasihatnya tidak dipedulikan oleh pemerintah Indonesia.

\section{Riwayat Organisasi HAMKA}

HAMKA aktif dalam gerakan Islam melalui organisasi Muhammadiyah. Beliau mengikuti pendirian Muhammadiyah mulai tahun 1925 untuk melawan khurafat, bid'ah, tarekat dan kebatinan sesat di Padang Panjang. Mulai tahun 1928 beliau mengetuai cabang Muhammadiyah di Padang Panjang. Pada tahun 1929 HAMKA mendirikan pusat latihan pendakwah Muhammadiyah dan dua tahun kemudian beliau menjadi konsul Muhammadiyah di Makassar. Kemudian beliau terpilih menjadi ketua Majelis Pimpinan Muhammadiyah di Sumatera Barat oleh Konferensi Muhammadiyah, menggantikan S.Y. Sutan Mangkuto pada tahun 1946. Pada tahun 1953, HAMKA dipilih sebagai penasihat pimpinan Pusat Muhammadiyah.

\section{Aktivitas Politik HAMKA}

Kegiatan politik HAMKA bermula pada tahun 1925 ketika beliau menjadi anggota partai politik Sarekat Islam. Pada tahun 1945, beliau membantu menentang usaha kembalinya penjajah Belanda ke Indonesia melalui pidato dan menyertai kegiatan gerilya di dalam hutan di Medan. Pada tahun 1947, HAMKA diangkat menjadi ketua Barisan Pertahanan Nasional, Indonesia.

Pada tahun 1955 HAMKA beliau masuk Konstituante melalui partai Masyumi dan menjadi pemidato utama dalam Pilihan Raya Umum. Pada masa inilah pemikiran HAMKA sering bergesekan dengan mainstream politik ketika itu. Misalnya, ketika partai-partai beraliran nasionalis dan komunis menghendaki Pancasila sebagai dasar negara. Dalam pidatonya di Konstituante, HAMKA menyarankan agar dalam sila pertama Pancasila dimasukkan kalimat tentang kewajiban menjalankan syariat Islam bagi pemeluknyan sesuai yang termaktub dalam Piagam Jakarta. Namun, pemikiran HAMKA ditentang keras oleh sebagian besar anggota Konstituante, termasuk Presiden Sukarno. Perjalanan politiknya bisa dikatakan berakhir ketika Konstituante dibubarkan melalui Dekrit Presiden Soekarno pada 1959. Masyumi kemudian diharamkan oleh pemerintah Indonesia pada tahun 1960. Meski begitu, HAMKA tidak pernah menaruh dendam terhadap Sukarno. Ketika Sukarno wafat, justru HAMKA yang menjadi imam salatnya. Banyak suara-suara dari rekan sejawat yang mempertanyakan sikap HAMKA. "Ada yang mengatakan Sukarno itu komunis, sehingga tak perlu disalatkan, namun HAMKA tidak peduli. Bagi HAMKA, apa yang dilakukannya atas dasar hubungan persahabatan. Apalagi, di mata HAMKA, Sukarno adalah seorang muslim.

Dari tahun 1964 hingga tahun 1966, HAMKA dipenjarakan oleh Presiden Soekarno karena dituduh pro-Malaysia. Semasa dipenjarakan, beliau mulai menulis 
Tafsir al-Azhar yang merupakan karya ilmiah terbesarnya. Setelah keluar dari penjara, HAMKA diangkat sebagai anggota Badan Musyawarah Kebajikan Nasional, Indonesia, anggota Majelis Perjalanan Haji Indonesia dan anggota Lembaga Kebudayaan Nasional Indonesia.

Pada tahun 1978, HAMKA lagi-lagi berbeda pandangan dengan pemerintah. Pemicunya adalah keputusan Menteri Pendidikan dan Kebudayaan Daoed Joesoef untuk mencabut ketentuan libur selama puasa Ramadan, yang sebelumnya sudah menjadi kebiasaan.

Idealisme HAMKA kembali diuji ketika tahun 1980 Menteri Agama Alamsyah Ratuprawiranegara meminta MUI mencabut fatwa yang melarang perayaan Natal bersama. Sebagai Ketua MUI, HAMKA langsung menolak keinginan itu. Sikap keras HAMKA kemudian ditanggapi Alamsyah dengan rencana pengunduran diri dari jabatannya. Mendengar niat itu, HAMKA lantas meminta Alamsyah untuk mengurungkannya. Pada saat itu pula HAMKA memutuskan mundur sebagai Ketua MUI.

\section{Aktivitas Sastra HAMKA}

Selain aktif dalam soal keagamaan dan politik, HAMKA merupakan seorang wartawan, penulis, editor dan penerbit. Sejak tahun 1920-an, HAMKA menjadi wartawan beberapa buah akhbar seperti Pelita Andalas, Seruan Islam, Bintang Islam dan Seruan Muhammadiyah. Pada tahun 1928, beliau menjadi editor majalah Kemajuan Masyarakat. Pada tahun 1932, beliau menjadi editor dan menerbitkan majalah al-Mahdi di Makasar. HAMKA juga pernah menjadi editor majalah Pedoman Masyarakat, Panji Masyarakat dan Gema Islam.

HAMKA juga menghasilkan karya ilmiah Islam dan karya kreatif seperti novel dan cerpen. Karya ilmiah terbesarnya ialah Tafsir al-Azhar (5 jilid). Pada 1950, ia mendapat kesempatan untuk melawat ke berbagai negara daratan Arab. Sepulang dari lawatan itu, HAMKA menulis beberapa roman. Antara lain Mandi Cahaya di Tanah Suci, Di Lembah Sungai Nil, dan Di Tepi Sungai Dajlah. Sebelum menyelesaikan roman-roman di atas, ia telah membuat roman yang lainnya. Seperti Di Bawah Lindungan Ka'bah, Tenggelamnya Kapal Van Der Wijck, Merantau ke Deli, dan Di Dalam Lembah Kehidupan merupakan roman yang mendapat perhatian umum dan menjadi buku teks sastera di Malaysia dan Singapura. Setelah itu HAMKA menulis lagi di majalah baru Panji Masyarakat yang sempat terkenal karena menerbitkan tulisan Bung Hatta berjudul Demokrasi Kita.

\section{Aktivitas Keagamaan}

Setelah peristiwa 1965 dan berdirinya pemerintahan Orde Baru, HAMKA secara total berperan sebagai ulama. Ia meninggalkan dunia politik dan sastra. Tulisan-tulisannya di Panji Masyarakat sudah merefleksikannya sebagai seorang ulama, dan ini bisa dibaca pada rubrik Dari Hati Ke Hati yang sangat bagus penuturannya. Keulamaan HAMKA lebih menonjol lagi ketika dia menjadi ketua MUI pertama tahun 1975. 
HAMKA dikenal sebagai seorang moderat. Tidak pernah beliau mengeluarkan kata-kata keras, apalagi kasar dalam komunikasinya. Beliau lebih suka memilih menulis roman atau cerpen dalam menyampaikan pesan-pesan moral Islam. Ada satu yang sangat menarik dari Buya HAMKA, yaitu keteguhannya memegang prinsip yang diyakini. Inilah yang membuat semua orang menyeganinya. Sikap independennya itu sungguh bukan hal yang baru bagi HAMKA. Pada zamam pemerintah Soekarno, HAMKA berani mengeluarkan fatwa haram menikah lagi bagi Presiden Soekarno. Otomatis fatwa itu membuat sang Presiden berang 'kebakaran jenggot'. Tidak hanya berhenti di situ saja, HAMKA juga terus-terusan mengkritik kedekatan pemerintah dengan PKI waktu itu. Maka, wajar saja kalau akhirnya dia dijebloskan ke penjara oleh Soekarno. Bahkan majalah yang dibentuknya "Panji Masyarat" pernah dibredel Soekarno karena menerbitkan tulisan Bung Hatta yang berjudul "Demokrasi Kita" yang terkenal itu. Tulisan itu berisi kritikan tajam terhadap konsep Demokrasi Terpimpin yang dijalankan Bung Karno. Ketika tidak lagi disibukkan dengan urusan-urusan politik, hari-hari HAMKA lebih banyak diisi dengan kuliah subuh di Masjid Al-Azhar, Jakarta Selatan.

\section{Wafatnya HAMKA}

Pada tanggal 24 Juli 1981 HAMKA telah pulang ke rahmatullah. Jasa dan pengaruhnya masih terasa sehingga kini dalam memartabatkan agama Islam. Beliau bukan sahaja diterima sebagai seorang tokoh ulama dan sastrawan di negara kelahirannya, bahkan jasanya di seantero Nusantara, ter masuk Malaysia dan Singapura, turut dihargai. Atas jasa dan karya-karyanya, HAMKA telah menerima anugerah penghargaan, yaitu Doctor Honoris Causa dari Universitas al-Azhar Cairo (tahun 1958), Doctor Honoris Causa dari Universitas Kebangsaan Malaysia (tahun 1958), dan Gelar Datuk Indono dan Pengeran Wiroguno dari pemerintah Indonesia

\section{Buah Pena BUYA HAMKA}

Kitab Tafsir Al-Azhar merupakan karya gemilang Buya HAMKA. Tafsir AlQuran 30 juz itu salah satu dari 118 lebih karya yang dihasilkan Buya HAMKA semasa hidupnya. Tafsir tersebut dimulainya tahun 1960. HAMKA meninggalkan karya tulis segudang. Tulisan-tulisannya meliputi banyak bidang kajian: politik (Pidato Pembelaan Peristiwa Tiga Maret, Urat Tunggang Pancasila), sejarah (Sejarah Ummat Islam, Sejarah Islam di Sumatera), budaya (Adat Minangkabau Menghadapi Revolusi), akhlak (Kesepaduan Iman \& Amal Salih ), dan ilmu-ilmu keislaman (Tashawwuf Modern).

\section{a. Pandangan Buya Hamka tetang pluralism}

Selepas Orde Lama, salah satu yang berkembang luas, adalah paham yang Buya Hamka sebut sebagai sinkritisme. Sinkritisme ala Orde Baru ini, ditandai ketika tahun 1968, Idul Fitri jatuh berdekatan dengan Hari Raya Natal. Maka timbul berbagai perayaan Halal bi Halal dan Natal gabungan, yang diselenggarakan oleh pemerintah di departemen-departemen. Acara Lebaran-Natal ini biasanya diawali 
dengan pembacaan ayat Al-Quran, kemudian dilanjutkan dengan pembacaan ayatayat Injil oleh pendeta atau pastor. ${ }^{13}$

Acara ini dikecam oleh Buya Hamka, katanya,”...kalau hal-hal seperti ini diadakan untuk toleransi, demi kesaktian Pancasila, atau demi mengamalkan dan mengamankan Pancasila, dengan sungguh-sungguh kita katakan bahwa, ini bukan toleransi, melainkan memaksa kedua belah pihak menjadi orang munafik, mengangguk-angguk menerima hal yang tak masuk diakal; dengan sengaja dan diatur, supaya membuktikan toleransi."

Mungkin inilah bibit-bibit, apa yang sekarang dinamakan pluralisme agama. Bagaimanapun sinkritisme sendiri bagian dari pluralisme agama. ${ }^{14}$ dan dilakukan demi sebuah toleransi agama yang dipaksakan. Konsekuensi dari penolakan acara semacam ini, bisa saja dituduh anti Pancasila dan tidak toleran, dan tidak menunjukkan kepribadian Indonesia. Buya Hamka pernah membalas tuduhan seperti ini dengan mengatakan, "Selama pena ini masih bisa menulis dan mulut Ini masih bisa berkata, kita katakan terus terang: Bukan begitu yang toleransi!."

Buya Hamka menunjuk orang-orang yang menganjurkan doa bersama, atau perayaan Lebaran-Natal dan semacamnya, bukanlah orang-orang yang mempunyai kesadaran agama, ,melainkan orang-orang sekuler, yang bagi mereka masa bodoh, apakah Tuhan satu atau beranak, sebab bagi mereka agama itu hanya Iseng!

Pendukung sekularisme di Indonesia semakin mendapat angin segar tatkala pada awal tahun 1970-an, Nurcholis Madjid menyampaikan pemikirannya yang berjudul 'Keharusan Pembaharuan Pemikiran dalam Islam dan Masalah Integrasi Ummat. ${ }^{15}$

Di masa Orde Baru sekularisme mendapat sokongan luar biasa dari pemerintah Soeharto, yang memang hendak meminggirkan Islam dari negara. Pemaksaan Pancasila sebagai asas tunggal, hingga dikerahkannya menteri Agama kabinetnya untuk mendorong sekularisme ala Orde Baru membuat ormas dan partai Islam saat itu PPP kewalahan. Apa daya, indoktrinasi sekuler ala Orde Baru dengan menunggangi Pancasila dan stigma ekstrim kanan yang dikalungkan pada gerakan politik yang mengusung Islam, membuat sekularisme menjadi buaian dan bualan indah yang melekat dalam sebagian benak rakyat Indonesia. ${ }^{16}$

\section{b. Pemikiran Teologi Hamka}

\footnotetext{
${ }^{13}$ Buya HAMKA, Dari Hati ke Hati, , Pustaka Panjimas Jakarta. 2002,

14 Tren Pluralisme Agama. Tinjauan Kritis, Dr. Anis Malik Thoha, Jakarta

${ }^{15}$ HM Rasjidi. Koreksi Terhadap Drs Nurcholis Madjid Tentang Sekularisasi”, Jakata: Bulan Bintang)

16 Faisal, Islam, Politics and Ideology in Indonesia : A Study of The Process of Muslim Acceptance of The Pancasila, (Disertasi di Institut of Islamic Studies McGill University. 1995.)
} 
Kalau kita mengakaji corak pemikiran Teologi Buya Hamka, bisa dilihat dalam beberapa tafsirannya atas ayat terkesan sebagai pemikir kalam rasional Namun di samping itu tidak pula mengatakannya beliau ini cenderung kepada Mu'tazilah - yang memberi tekanan kuat pada kemerdekaan manusia dalam berkehendak dan berbuat. Sikap teologis ini melahirkan semangat kerja keras dan tidak mau menyerah pada keadaaan dalam diri Buya Hamka, sehingga mematri kredo hidupnya dengan ungkapan "sekali berbakti sesudah itu mati".

Yunan Yusuf meneliti delapan masalah kalam, merupakan pemikiran Buya Hamka yakni: (1) kekuatan akal; (2) fungsi wahyu; (3) free will dan predestination; (4) konsep iman; (5) kekuasaan dan kehendak mutlak Tuhan; (6) keadilan Tuhan; (7) perbuatan-perbuatan Tuhan; dan (8) sifat-sifat Tuhan. Semua entri point ini membuktikan bahwa Buya Hamka dalam dua masalah pertama menganut aliran Maturidiyah Bukhara, sedangkan enam masalah terakhir sejalan dengan aliran Mu'tazilah. ${ }^{17}$

Dalam masalah "free will" dan "predestination" serta konsep iman, Bapak Dr. Yunan menemukan pemikiran Hamka tentang kebebasan manusia dalam berkehendak dan berbuat. Dengan akalnya manusia bisa menimbang mana yang buruk dan mana yang mendatangkan kebaikan. Namun, Buya Hamka tetap mengakui jangkauan takdir sebagai manifestasi dari kekuasaan Tuhan. Dengan kata lain, secara metaforis bisa dinyatakan bahwa "malam bercermin kitab suci, siang bertongkatkan besi".

Sejalan dengan itu, konsep iman tidak hanya meniscayakan sekedar tasdiq tetapi juga ma'rifah dan 'amal. Ini didasarkan pada keberadaan teologi sebagai sebuah paham keagamaan yang akan menentukan bentuk watak sosial penganutnya, serta memberi warna pada tindakan dan tingkah laku dalam setiap aspek kehidupannya, yang pada gilirannya akan memberikan arah pada jalan hidup itu sendiri. Adapun kekuasaan dan kehendak mutlak Tuhan dibatasi oleh kebebasan memilih (ikhtiyar) berdasarkan pertimbangan akal yang diberikan Tuhan kepada manusia. Inilah yang meniscayakan kekuasaan dan kehendak mutlak Tuhan tidak berlaku sepenuhnya. Dengan kata lain, pemberian akal bagi manusia tidak mempunyai arti, bila manusia tidak diberikan kebebasaan untuk memilih. Sementara, keadilan Tuhan didefinisikan oleh Buya Hamka sebagai balasan atas semua perbuatan manusia, meskipun sebesar zarrah (bentuk terkecil benda) sekalipun. Kezaliman mustahil bagi Allah, walau tidak ada yang kuasa membendung jika memang Allah menghendaki.

Hal ini erat kaitannya dengan keyakinan Hamka bahwa perbuatan-perbuatan Tuhan terletak pada kewajiban-Nya untuk melakukan yang baik. Paham ini dibangun dari realitas alam semesta yang berlaku atas Hikmah Kebijaksanaan Yang Maha

17 Yunan Yusuf, Corak Pemikiran Kalam Tafsir Al-Azhar, (Jakarta: Penerbit Pustaka Panjimas, 1990) 
Tinggi. Bila tidak, mungkin sampai sekarang kita tidak bisa hidup dalam siklus kehidupan alam yang berjalan normal dan baik.

Penafsiran Buya Hamka atas Sifat-sifat Tuhan sejalan dengan pemikiran rasional ketika berbicara tentang antropomorfisme. Kata-kata "wajh" berarti zat Allah dan ridha-Nya, "yad" adalah kekuasaan dan restu-Nya, "yamin" berarti hakekat "qudrat ilâhiyat"-Nya, "ja'a rabbuka" ditafsirkan dengan telah datang ketentuan atau perintah Tuhan, dan beberapa contoh lainnya. Sikap Buya Hamka ini dipengaruhi oleh tafsiran surat Ali Imran ayat 7 bahwa Tuhan tidak melarang untuk menakwilkan ayat-ayat mutasyâbihât (samar). ${ }^{18}$

Adapun dalam masalah ru'yatullah (melihat Allah), Hamka terlihat menganut paham rasional bahwa Tuhan tidak dapat dilihat dengan mata kepala kelak di akhirat, melainkan dengan mata hati, karena kitapun belum mampu melihat alam semesta, baik yang berada di dalam maupun di luar diri kita sendiri. Dalam memahami masalah kemakhlukan al-Qur'an, Hamka marangkum kedua aliran, baik yang rasional maupun tradisional, dengan kecenderungan untuk menghindarkan diri dari perdebatan ilmu kalam. Dia menghimbau agar Mu'tazilah dan Ahlus Sunnah modern tidak bertengkar lagi tentang masalah ini.

Semua pandangan Buya Hamka dalam menafsirkan ayat yang erat kaitannya dengan pemikiran kalam ini berlandaskan pada sikap untuk mencari alternatif atas perdebatan klasik seputar masalah kalam. Ia menyebutnya dengan "jalan tengah", yakni tidak mempersoalkan secara tajam perbedaan dalam hal tersebut, yang seringkali terjebak pada buaian konflik berkepanjangan tanpa menyuguhkan manfaat praktis bagi umat.

Yunan Yusuf Beliau Terkesan sangat hati-hati untuk mengklaim Hamka sebagai penganut Mu'tazilah, karena Buya Hamka selalu menyebut dirinya sebagai penganut Ahlus Sunnah wal Jama'ah. Pemikiran kalamnya yang identik dengan pemikiran Mu'tazilah tersebut, kelihatannya lebih dipengaruhi oleh realitas kontemporer yang menuntut tindakan atas dasar rasio serta mendahulukan inisiatif pribadi atas pertimbangan tradisi, atau sikap rasional dengan pijakan kuat pada nashnash agama. Hal ini dianggap sebagai jalan terbaik untuk memacu berbagai ketertinggalan umat Islam.

\section{c. Pemikiran Tasawuf Hamka}

Pemikiran tasawuf Hamka tertuang Dalam bukunya yang berjudul "tasawuf modern" dimana dia mencoba membahasakan tasawuf melalui "bahasa bumi" yang mudah dipahami oleh masyarakat umum. ${ }^{19}$ Dalam bukunya tersebut hamka

\footnotetext{
${ }^{18}$ http://www.psq.or.id/perpustakaan_detail.asp?mnid=31\&id=5
}

${ }^{19}$ Samsul Nizar, Seabad Buya Hamka (Jakarta: Kencana Prenada Media Group, 2008), h. 47. 
memberikan apresiasi yang wajar terhadap penghayatan esoteris islam, sekaligus juga peringatan bahwa esoterisme itu hendaknya tetap terkendalikan oleh ajaran standar syari'ah. Disini ia menghendaki suatu penghayatan keagamaam esoteris yang mendalam, akan tetapi tidak perlu melakukan pengasingan diri ('uzlah), melainkan tetap aktif melibatkan diridalam masyarakat. Pemikiran tasawuf hamka lebih bersifat "neo sufisme" ${ }^{20}$ dimana dia meletakkan dasar-dasar sufisme baru yang disebut tasawuf modern atau tasawuf positif yang berdasar pada prinsip tauhid, bukan pencarian pengalaman (mukasyafah), dimana jalan tasawufnya itu melalui sikap zuhud yang dapat dilaksanakan dalam peribadahan resmi sikap zuhud, maksudnya untuk dekat dengan tuhan itu dengan cara memanfaatkan peribadahan sebagai media tasawuf dimana dalam artian disamping melaksanakan perintah agama juga mencari hikmah dibalik semua perintah ibadah itu yang nantinya menghasilkan releksi hikmah yang berupa sikap positif terhadap hidup dalam wujud memiliki etos sosial yang tinggi, jadi tidak perlu harus menyendiri menjauhi kehidupan dunia. Penghayatan tasawuf hamka itu berupa pengalaman takwa yang dinamis, bukan ingin bersatu dengan tuhan, adapun refleksi tasawuf menurut hamka yaitu berupa menampakkan makin meningginya kepekaan sosial dalam diri si sufi. Jadi intinya secara garis besar, konsep dasar sufistik menurut hamka adalah sufisme yang berorientasi ke depan.

Corak Pemikiran Tasawuf Hamka seakan mengacu pada tasawuf falsafi, mengingat konsepsi tentang tuhan merupakan perkembangan lebih lanjut dari pemikiran para ahli kalam dan filusoof. ${ }^{21}$ Corak pemikiran tasawuf Hamka terwarnai dari pemikirannya Ibn Taimiyah, Imam Al Ghazali, dan juga Ibn Qayyim al Jazwiyah. Hamka melalui tasawuf modernnya mengembalikan tasawuf pada posisi yang sebenarnya, yaitu sebagai wahana peribadatan yang dapat mendekatkan hamba dengan sang penciptanya, disamping itu hamka telah memainkan perannya yang cukup besar dalam mengembangkan sikap asketik bagi umat islam. Hamka mencoba menonjolkan segi-segi kesufian dari sisi ibadah islam tanpa harus mengikuti ibadah tareqot.

\section{d. Pemikiran Hamka tentang Pendidikan.}

Pendidikan dalam pandangan Hamka terbagi 2 bagian yaitu:

1. Pendidikan jasmani, pendidikan untuk pertumbuhan \& kesempurnaan jasmani serta,

2. Pendidikan ruhani, pendidikan untuk kesempurnaan fitrah manusia dengan ilmu pengetahuan \& pengalaman yang didasarkan pada agama.

Keduanya memiliki kecenderungan untuk berkembang dengan melalui pendidikan, karena pendidikan merupakan sarana yang paling tepat dalam menentukan perkembangan secara optimal kedua unsur tersebut. Dalam pandangan

\footnotetext{
${ }^{20}$ Solihin, Ilmu Tasawuf, (Bandung: CV. Pustaka Setia, 2011), h. 276.

${ }^{21}$ Lihat. http://amir14.wordpress.com/tasawuf-hamka/ (3 Maret 2016)
} 
Islam kedua unsur tersebut dikenal dengan istilah fitrah.Titik sentral pemikiran Hamka dalam pendidikan Islam adalah "fitrah pendidikan tidak saja pada penalaran semata, tetapi juga akhlakul karimah". Fitrah setiap manusia pada dasarnya menuntun untuk senantiasa berbuat kebajikan \& tunduk mengabdi sebagai kholifah fil ardh maupun 'abdulloh. Ketiga unsur tersebut adalah akal, hati, \& pancaindra yang terdapat pada jasad manusia. Perpaduan ketiga unsur tersebut membantu manusia untuk memperoleh ilmu pengetahuan dan membangun peradabannya, memahami fungsi kekhalifahannya, serta menangkap tanda-tanda kebesaran Allah. ${ }^{22}$

1. Pengertian dan Tujuan Pendidikan

Hamka membedakan makna pendidikan dan pengajaran. Menurutnya pendidikan adalah serangkaian upaya yang dilakukan pendidik untuk mendidik membantu membentuk watak budi akhlak dan kepribadian peserta didik,sedangkan pengajaran yaitu upaya untuk mengisi intelektual peserta didik dengan sejumlah ilmu pengetahuan. Keduanya memuat makna yang integral dan saling melengkapi dalam rangka mencapai tujuan yang sama,sebab setiap proses pendidikan didalamnya terdapat proses pengajaran.Demikian sebaliknya proses pengajaran tidak akan banyak berarti apabila tidak dibarengidengan proses pendidikan. ${ }^{23}$

Menurut Hamka ada tiga term yang digunakan para ahli untuk menunjukkan istilah pendidikan Islam:

a. Ta'lim: Aspek-aspek pengetahuan dan ketrampilan yang dibutuhkan seseorang dalam hidupnya dan pedoman perilaku yang baik.

b. Tarbiyah: Pengembangan ilmu dalam diri manusia dan pemupukan akhlak yakni pengalaman ilmu yang benar dalam mendidik pribadi.

c. Ta'dib: Penguasaan ilmu yang benar dalam diri seseorang agar menghasilkan kemantapan amal dan tingkah laku yang baik.

Dari ketiganya Hamka lebih condong dalam istilah Tarbiyah, karena menurutnya tarbiyah kelihatannya mengandung arti yang lebih komprehensif dalam memaknai pendidikan Islam, baik vertikal maupun horizontal (hubungan ketuhanan dan kemanusiaan). Adapun prosesnya adalah pemeliharaan dan pengembangan seluruh potensi (fitrah) peserta didik, baik jasmaniah maupun rohaniah. Dalam pembahasan hal ini hampir sama dengan pemikiran Syed M.Naquib Al-Attas namun beliau lebih spesifik dalam ta'dib atau adab.

Adapun pandangan Hamka mengenai Tarbiyah yaitu:

a. Menjaga dan memelihara pertumbuhan fitrah (potensi) peserta didik untuk mencapai kedewasaan.

22 Syamsul Kurniawan dan Erwin Makhrus, Jejak Pemikiran Tokoh Pendidikan Islam (Jogjakarta: Ar-Ruzz Media. 2011.) h. 229-230

${ }^{23}$ Ramayulis \& Syamsul Nizar, Ensiklopedi Tokoh Pendidikan Islam (Ciputat: Quantum Teaching, 2005), h. 226 
b. Mengembangkan seluruh potensi yang dimilikinya, dengan berbagai sarana pendukung (terutama bagi akal dan budinya).

c. Mengarahkan seluruh potensi yang dimiliki peserta didik menuju kebaikan dan kesempurnaan seoptimal mungkin.

Kesemua proses tersebut kemudian dilaksanakan secara bertahap sesuai dengan irama perkembangan diri peserta didik.

Adapun tujuan pendidikan menurut Hamka memiliki 2 dimensi yaitu bahagia dunia akhirat. Untuk mencapai hal tersebut dapat diperoleh melalui ibadah. Oleh karena itu, segala proses pendidikan pada akhirnya bertujuan agar dapat menuju dan menjadikan anak didik sebagai abdi Allah. Dengan demikian tujuan pendidikan Islam menurut Hamka sama dengan tujuan penciptaan manusia itu sendiri, yakni untuk mengabdi dan beribadah kepada Allah. Ia mengatakan bahwa ibadah adalah mengakui diri sebagai budak atau hamba Allah, tunduk kepada kemauan-Nya, baik secara sukarela maupun terpaksa.[6]

2. Tugas dan Tanggung Jawab Pendidik

Tugas pendidik secara umum adalah memantau mempersiapkan dan mengantarkan peserta didik untuk memiliki ilmu pengetahuan yang luas, berakhlak mulia dan bermanfaat bagi kehidupan masyarakat secara luas. Dengan pelaksanaan pendidikan yang demikian peserta didik diharapkan mampu mewujudkan tujuan hidupnya baik secara horizontal (kholifah fil ard) maupun vertikal ('abd Allah). Dalam hal ini setidaknya ada tiga intitusi atau pihak yang ikut andil dalam bertugas dan bertanggungjawab dalam pelaksanaan pendidikan yaitu:

a. Lembaga pendidikan informal

Keluarga merupakan lembaga yang mempengaruhi perkembangan akhlak dan pola pikir anak, dan hanya keluarga yang demokratis akan mampu mengembangkan dinamika secara maksimal. Orang tua memegang peranan penting bagi pembentukan kepribadian terutama akhlak seorang anak. Dalam hal ini orang harus menjadi contoh yang baik dan berakhlak sebelum membentuk karakter anak untuk mempunyai keprubadian yang baik. Adapun rambu-rambu untuk kedua oarang tua dalam melaksanakan pendidikan terhadap anak yaitu:

1. Mengajarkan anak untuk cepat bangun dan jangan banyak tidur.

2. Menanamkan didikan akhlak yang mulia dan hidup sederhana.

3. Mengajarkan cinta kasih dan kehidupan harmonis melalui cerita-cerita.

4. Membiasakan untuk selalu percaya diri dan mandiri.

Hal ini memang nampak sekali seperti adanya keterpaksaan namun bukan berarti sang orang tua berkuasa penuh dalam gerak anak, melainkan orang tua menuntun dan mengontrol agar kebebasan gerak potensi yang dimiliki anak terealisasikan secara maksimal.

b. Lembaga pendidikan formal

Sekolah merupakan lembaga pendidikan yang tersusun secara terencana dan sistematis. Sekolah bertugas mengembangkan seluruh potensi yang ada dalam peserta didik secara maksimal sehingga memiliki sejumlah kemampuan yang dapat dipergunakan untuk melaksanakan fungsinya ditengah-tengah masyarakat. Dalam hal 
ini seorang guru bertugas membimbing peserta didiknya untuk memiliki ilmu yang luas,berakhlak mulia,dan bermanfaat bagi masyarakat luas.

c. Lembaga pendidikan non formal

Masyarakat merupakan lembaga pendidikan yang sangat luas dan berpengaruh dalam proses pembentukan kepribadian seorang anak. Lembaga ini merupakan lembaga pendukung dalam pelaksanaan proses pendidikan secara praktis. Sesuai dengan fitrahnya yakni makhluk sosial yang tidak dapat hidup tanpa adanya interaksi dan membutuhkan bantuan orang lain yang ada disekitarnya. Eksistensinya yakni saling bekerja sama dan saling mempengaruhi antara satu dan yang yang lainnya. Melalui bentuk komunitas masyarakat yang harmonis, menegakkan akhlak nilai akhlak,dan hidup sesuai dengan nilai-nilai ajaran Islam, akan dapat mewujudkan tatanan kehidupan yang tentram. Kondisi masyarakat yang seperti inilah yang merupakan ciri masyarakat ideal bagi terlaksananya pendidikan secara efekif dan dinamis. Oleh karena itu, memformulasikan sistem pendidikan diperlukan pendekatan psikologis dan sosiologis, dan pendekatan dilakukan dengan mengakomodir dan menyeleksi sistem nilai sosial (adat) serta dengan pendekatan ini pendidikan mampu memainkan perannya sebagai agent of change dan agent of social culture. ${ }^{24}$

Melalui pemikirannya, Hamka memperlihatkan relevansi yang harmonis antara ilmu-ilmu agama dan umum. Eksistensi agama bukan hanya sekedar melegitimasi sistem sosial yang ada, melainkan juga perlu memperhatikan dan mengontrol perilaku manusia secara baik. Perilaku sistem sosial akan lebih hidup tatkala pendidikan yang dilaksanakan ikut mempertimbangakan dan mengayomi dinamika fitrah peserta didik serta mengintegralkan perkembangan ilmu-ilmu agama dan umum secara profesional. Dengan pendekatan seperti ini pendidikan akan dapat memainkan peranan nya sebagai motivator dan sekaligus pengendali sistem sosial (social control) secara efektif.

\section{Kesimpulan}

1. Nurcholis lahir dan dibesarkan di lingkungan keluarga kiai terpandang di Mojoanyar, Jombang, Jawa Timur, pada tanggal 17 Maret 1939. Ayahnya, KH Abdul Madjid, dikenal sebagai pendukung Masyumi. Setelah melewati pendidikan di pesantren (Pesantren Darul 'ulum Rejoso, Jombang, Jawa Timur, sampai tahun 1955, dan kemudian Pesantren Darus Salam, Gontor, Ponorogo, Jawa Timur sampai tahun 1960), ia menempuh studi kesarjanaan di IAIN Syarif Hidayatullah Jakarta (mendapat BA dalam Sastera Arab th. 1965, dan Doktorandus- Sastera Arab th.1968). Kemudian tokoh HMI (Menjabat sebagai ketua HMI dua periode/1966-1971) ini menjalani studi doktoralnya di Universitas Chicago- Amerika Serikat (1978-1984), dengan disertasi tentang Filsafat dan Kalam Ibnu Taimiyah. Bidang yang diminatinya selain Filsafat,

\footnotetext{
${ }^{24}$ Ramayulis \& Syamsul Nizar, Op. Cit, h 268-274
} 
adalah: Pemikiran Islam, Reformasi Islam, Kebudayaan Islam, Politik dan Agama, Sosiologi Agama, serta Politik negara-negara berkembang.

2. Biografi HAMKA (1908-1981), adalah akronim kepada nama sebenar Haji Abdul Malik bin Abdul Karim Amrullah. Ia adalah seorang ulama, aktivis politik dan penulis Indonesia yang amat terkenal di alam Nusantara. Ia dilahirkan pada tanggal 17 Februari 1908 di kampung Molek, Maninjau, Sumatera Barat, Hindia Belanda (saat itu). Ayahnya ialah Syeikh Abdul Karim bin Amrullah atau dikenali sebagai Haji Rasul, seorang pelopor Gerakan Islah (tajdid) di Minangkabau, sekembalinya dari Makkah pada tahun 1906. Hamka mendapat pendidikan rendah di Sekolah Dasar Maninjau sehingga kelas dua. Ketika usia HAMKA mencapai 10 tahun, ayahnya telah mendirikan Sumatera Thawalib di Padang Panjang. Di situ Hamka mempelajari agama dan mendalami bahasa Arab. Hamka juga pernah mengikuti pengajaran agama di surau dan masjid yang diberikan ulama terkenal seperti Syeikh Ibrahim Musa, Syeikh Ahmad Rasyid, Sutan Mansur, R.M. Surjopranoto dan Ki Bagus Hadikusumo.

3. Nurchalish Madjid dalam pemikirannya tentang sekulerisasi, mengatakan bukan penerapan sekularisme dan mengubah kaum muslimin menjadi sekularis." Tetapi dimaksudkan untuk menduniawikan nilai-nilai yang sudah semestinya bersifat duniawi dan melepaskan umat Islam dari kecenderungan untuk mengukhrowikannya. Jika Indonesia kembali pada fundamentalisme Islam ibarat bahaya narkotika yang selalu membekas dalam diri manusia, pernyataan itu sesuai dengan cuplikan pidatonya yang menghebohkan ketika menyampaikan pidato keagamaan di Taman Ismail Marzuki 21 Oktober 1992. paham Pluralitas masyarakat adalah bagian amat penting dari tatanan masyarakat maju. Dalam paham itulah dipertaruhkan, antara lain sehatnya demokrasi dan keadilan. Pluralisme tidak saja mengisyaratkan adanya sikap bersedia mengakui hak kelompok lain atau ada, tetapi juga mengandung makna kesediaan berlaku adil kepada kelompok lain itu atas dasar perdamaian dan saling menghormati. Islam bersifat inklusif dan merentangkan kearah pluralis dengan menyatakan bahwa setiap agama mempunyai ekspresi keimanan terhadap tuhan yang sama ibarat roda yang berputar, pusat roda tersebut adalah tuhan yang sama melalui jalan berbagai agama yang heterogen tapi satu makna. Jadi Pluralisme adalah sunnatullah sebuah aturan khusus dari tuhan yang tidak akan berubah, sehingga tidak mungkin juga dilawan atau diingkari.

Buya Hamka, menolak dengan keras apa yang disebut toleransi agama, dan juga menolak dengan keras tentang pluralisme agama juga menolak paham sekularisme. Penolakan sekularisme inilah yang membuat Hamka masuk penjara. Penghayatan tasawuf hamka itu berupa pengalaman takwa yang dinamis, bukan ingin bersatu dengan tuhan, adapun refleksi tasawuf menurut hamka yaitu berupa menampakkan makin meningginya kepekaan sosial dalam diri si sufi. Jadi intinya secara garis besar, konsep dasar sufistik menurut hamka adalah sufisme yang berorientasi ke depan. Sedangkan konsep Pendidikan dalam pandangan Hamka terbagi 2 bagian yaitu:

(1) Pendidikan jasmani, pendidikan untuk pertumbuhan \& kesempurnaan jasmani serta, (2). Pendidikan ruhani, pendidikan untuk kesempurnaan fitrah manusia dengan 
ilmu pengetahuan \& pengalaman yang didasarkan pada agama. Keduanya memiliki kecenderungan untuk berkembang dengan melalui pendidikan, karena pendidikan merupakan sarana yang paling tepat dalam menentukan perkembangan secara optimal

\section{DAFTAR PUSTAKA}

Adnin Armas, dkk, Menelusuri Gagasan Sekularisasi Nurcholis Majid, Jurnal Tsaqafah Jurnal Ilmu Pengetahuan dan Kebudayaan Islam, ( Volume 4, No.2, Jumadal Ula 1428).

Barth, Karl Ethics, (New York: The Seabury Press, 1981) dikutip oleh Nur Cholis Madjid, Islam Doktrin dan Peradaban, Jakarta: Paramadina, 2005.

Faisal, Islam, Politics and Ideology in Indonesia : A Study of The Process of Muslim Acceptance of The Pancasila, Disertasi di Institut of Islamic Studies McGill University. 1995.

HAMKA, Dari Hati ke Hati, , Pustaka Panjimas Jakarta. 2002,

Handrianto, Budi 50 Tokoh Islam Liberal Indonesia, Jakarta Timur: Hujjah Press 2007.

http://amir14.wordpress.com/tasawuf-hamka/ (3 Maret 2016)

http://www.psq.or.id/perpustakaan_detail.asp?mnid=31\&id=5

Jaringan Islam Liberal, Ijtihad Islam Liberal, Jakarta: Jaringan Islam Liberal, 2005.

Kurniawan Syamsul dan Erwin Makhrus, Jejak Pemikiran Tokoh Pendidikan Islam Jogjakarta: Ar-Ruzz Media. 2011.

Madjid, Nur Cholis. Islam Doktrin dan Peradaban, Jakarta: Paramadina, 2005.

Nizar, Ramayulis \& Syamsul Ensiklopedi Tokoh Pendidikan Islam Ciputat: Quantum Teaching, 2005

Qodir, Abdul Jejak Langkah Pemikiran Islam di Indonesia, Bandung: Pustaka Pelajar, 2004.

Rakhmat, Jalaluddin Islam dan Pluralisme Akhlaq Qur'an Meyikapi Perbedaan, Jakarta: Serambi Ilmu Semesta, 2006.

Rasjidi. HM Koreksi Terhadap Drs Nurcholis Madjid Tentang Sekularisasi”, Jakata: Bulan Bintang

Samsul Nizar, Seabad Buya Hamka Jakarta: Kencana Prenada Media Group, 2008.

Solihin, Ilmu Tasawuf, Bandung: CV. Pustaka Setia, 2011.

Yunan Yusuf, Corak Pemikiran Kalam Tafsir Al-Azhar, Jakarta: Penerbit Pustaka Panjimas, 1990 
